\title{
CHILD MARRIAGE IN SHORT STORIES FROM INDONESIA AND BANGLADESH: VICTOR, SURVIVOR, AND VICTIM
}

\author{
Novita Dewi \\ Sanata Dharma University \\ novitadewi@usd.ac.id; novitadewi9@gmail.com \\ DOI: https://doi.org/10.24071/ijhs.2018.020106 \\ received 25 July 2018; revised 5 August 2018; accepted 3 September 2018
}

\begin{abstract}
Early marriage is a total destruction to the human rights of children. Contrary to the conviction that child marriage in rural, developing countries is inextricably linked with their cultural backwardness, violence against women need to be examined and addressed in terms of the specific socio-economic and cultural conditions as to why girls, adolescents and young women are forced to live and marry in their young age. This article examines two shorts stories from Indonesia to be analyzed comparatively with another story from Bangladesh to show the limit of mainstream feminist perspectives that often put the blame on minority cultures. The present study reveals that first, child marriages in both countries are largely driven by such factors as poverty, economic dependency, lack of education, and dowry in Bangladesh's case. Secondly, the ways in which authors depict child marriages vary, i.e. it is either perpetuating the violence in child marriage, or critically depicting child marriage as an aberrant patriarchal practice. Taken together, the child brides play their respective role as victor, survivor, or victim.
\end{abstract}

Keywords: child marriage, feminism, normalization, multiculturalism

\section{Introduction}

In 2011, the world was shocked by the heartbreaking news of child marriage practices in different parts of the world shown in the cover of the National Geographic magazine by the photographer Stephanie Sinclair for her article entitled "Too Young to Wed" (Harlan, 2015). It features a red-veiled girl Surita Shreshta Balami, 16, screaming in protest over a marriage procession that carries her to a new home with her husband Bishal Shrestha Balamani, 15, in the village of Kagati, Kathmandu Valley, Nepal. Since witnessing the horrific events in 2003 when several young girls in one province in Afghanistan burnt themselves rather than being forced to marry, Sinclair was a determined advocate to end this cruel practice. The young girls she interviewed testified that they chose to die than to live a terrible life under such torture as rape, abortion and divorce. Sinclair said that early marriage was performed in at least 50 countries in the world with a startling number, i.e. 39,000 marriages every single day. It means that two girls 
per second were sacrificed in forced marriages, sometimes with men who are much older. Sinclair's photos paved the way for the formation of a non-profit foundation "Too Young to Wed" which she built in 2012.

This article is to discuss the representation of early marriage in two short stories set Indonesia and one short story from Bangladesh. It would seem that in both Bangladesh and Indonesia, as in other less developed countries, the practice of child marriage is largely driven by socio-economic factors, including poverty, economic dependency, financial incentives and the practice of dowry, as well as lack of access to education and health services.

As reported in the Journal of Health, Population and Nutrition (2012), 82\% of women in Bangladesh aged 20-49 years got married before the age of 18 years, and $63 \%$ of marriages took place before the age of 16 years. There have been attempts to lower the number of child marriage that is proven to be harmful for the health of the mother and child, either through formal and informal education as well as the revision of the law that set the age limit for the minimal age of 19 for marriage in the country.

Although there are already laws that restrict early marriage, Indonesia, likewise, is ranked seventh among the ten countries with the highest number of child marriage; while India and Bangladesh are on the, respectively, first and second place. In Indonesia, Article 7 of Law No. 1 of the 1974 Marriage Law allows marriage only if the man has reached the age of 19 years and 16 years for the woman. It is also stipulated by the law that the basis for a marriage is the consent of the bride; and that of the parents for the bride who is not yet 21 years old. Dispensation against the age limit may be granted by the Court or other officers appointed by the parents of both sides (Susetyo, 2010). However, according to Plan International, Getting The Evidence: Asian Child-Marriage Initiative (2015), an estimated one out of every five girls in Indonesia get married before the age of 18 years. Child marriage in Indonesia is more common in rural areas. West Sulawesi, for example, is recorded as the region with the highest rate of child marriage before the age of 15 because some people regard this practice as a cultural tradition that has long been rooted. The community accept it as part of the social structure, hence they rarely question about the effects and consequences posed by early marriages.

Suffice to say that for now, early marriage is not infrequently associated with the normalization of violence of men against women and children (girls). Such marriage is often seen as a way out for the bad stigma that afflicts a girl due to a sexual experience outside of wedlock, victim of rape, and various other forms of sexual abuse. The aim of this article is to examine how male cruelty toward (young) women is imagined and often taken for granted as being a normal practice in different ways in different countries, like Bangladesh and Indonesia; and how the varied interpretations thereof are respectively represented in the three child bride's stories.

\section{Literature View}

There is an assumption that women of the minority groups (read: Eastern, non-Western) have become victims of their own culture. Cultural practices within the multicultural society often appear conflicting with the feminist views (from the West) in reading the ways men treat women. Women in the third world culture 
are considered more subordinate compared to experienced women in the Western world, as it has been discussed at length and refuted by, for example, Mohanty (1988), Suleri (1992) and Ang (2003).

While it may be true that many values in a multicultural society are not prowomen (Okin, 1998), Volpp (2001) proposes a constructive dialogue of feminismmulticulturalism in order to revisit the biased opinions of the European feminism. That minority culture is often seen to oppress women is a view that comes from the colonial ideology. So imposing is this view that it claims the superiority of the rational Western culture vis-à-vis the barbaric and irrational other. In addition to the historical legacy of colonialism, Volpp considers the origins of liberalism, the depiction of the feminist subject, and the use of binary logic that have all obscured cultural strengths and multicultural experience of women's life. Indeed, multicultural/minority culture itself is never static but constantly changing and negotiable with the times. Such a crude feminism perspective retains the patriarchy, cruelty and the overturning of the dignity of women it otherwise seeks to challenge. Therefore, an analysis of early marriages in literature will be placed in the context of gender studies with postcolonial perspectives. Using the tri-prong strategy of feminism-multiculturalism-postcolonialism, the discussion aims to reveal the power-relations and their implications that occur in the three stories chosen to discuss.

\section{Findings and Discussion}

\section{Précis of the Short Stories}

The first story by Ahmad Tohari, "Minem Gave Birth to a Baby" (English version of "Si Minem Beranak Bayi") is set in a dry limestone hill village in Indonesia where Kasdu rushes back home to meet his 14-year-old wife Minem who has just given birth to a premature baby -2 months ahead of time. The baby is forced out from Minem's womb when she fells downhill with a large earthen jar full of water in her hand. Kasdu is too lazy to fetch some water from the other neighboring village when a prolonged drought hit the region. Still puzzled by the incident, the young father walks his way quickly to see his in-laws to tell the news only to meet Minem's father who is equally baffled that his child can produce a child. Impatient by her husband's exaggerated response, Minem's mother reprimands him that she too was 14 when giving birth to Minem. Still amazed, Minem's father puts a proud smile on his face thinking how easily his daughters meet their soul mates; Next month the family is to celebrate the wedding of Minem's sister, twelve-year-old Minah.

The second story "Inem" was written by the famous Indonesian writer Pramoedya Ananta Toer after his release from 29-month-imprisonment by the Dutch Indies government. Presumably a semi-autobiographical in nature, the story is told by a six-year-old boy Muk (also Pram's nickname) about a girl two years older than he is who stays with his family to help Muk's mother cooking in the kitchen or, at times, accompanying Muk and his younger siblings to play. Till one day Inem tells the narrator that she is going to get married. Not only Muk, his mother is also baffled because Inem is only a child. When Inem's mother who lives nearby comes to take the girl back, argument ensues between Muk's mother and Inem's mother. Mbok Inem is determined to marry her daughter off with 17year-old Markaban, son of a wealthy cattle trader, ignoring as she does Muk's 
mother advice to avoid child marriage for health reason. Inem's marriage however is not a happy one, for Markaban is a sex maniac and wife-beater. Having divorced her husband, Inem begs Muk's mother to return to the family again whilst asking for protection. To the child narrator's disappointment, his noble decent mother refuses to let the 9-year-old divorcee stay in the house with male children out of respect.

Set against women's daily life in Bangladesh, the last short story "Seduction" by Razia Sultana Khan tells of Halima, a girl who is forced into a marriage at a young age. Her routine chore involves helping her mother-in-law preparing meals for the family in the morning and serving the husband's needs of the flesh in the evening. Halima's husband quickly makes Halima tired of life in a marriage without love. During the daytime, the lonely wife is often caught stealing glances through the slats on the window of her room facing Aga Sadeque Road, as she is waiting for the touring cinema to pass by. The mother-in-law then makes her busy with embroidery work, until one afternoon, Halima is attracted by the charm of a young chai peddler who looks more manly and muscular than her thin, pale husband. Halima is thrilled and with mixed feeling receives the chai from him brought to her by nine-year-old Ahsan, the son of Halima's neighbor. In fact, Chai Bhaia gives this free sherbet drinks to everyone for free before selling it later for one paisa per cup. When the much awaiting Chaiwallah is no longer seen selling chai on a pushcart for he is now selling it in a tea shop, Halima willingly gives four paisa to Ahsan to get her chai nonetheless.

\section{Theory Application}

All girls in "Minem Gave Birth to a Baby", "Inem, and "Seduction" are married to men from rich families when they are very young, respectively, 13, 8, and 16, to alleviate each family's financial problem. To begin with the story set in Bangladesh, Halima is expected to help reduce the burden of the family. In India and most South Asian countries including Bangladesh, the tradition surrounding early marriage, dowry, and arranged marriage still continue since colonial times, especially in rural areas, because this custom is loaded with religious, political, and financial systems (Subramanian, 2010). Poverty is one of the main reasons why Bangladeshi families marry off their daughters. In addition, the marriage of children reduces the financial hardship of the family which is then passed on to the daughters. "You'll be the oldest daughter-in-law", Halima's mother says, "you will be respected and ... have responsibilities." (Khan, 2010, p. 119). The girl who still loves to romp in the yard with her little friends, two birds named Tuni and Mooni, is suddenly disconnected from the world of her childhood. Her husband's family house is larger and more comfortable to his mother's home. In the daytime, however, the space and mobility of the young wife is confined to a narrow room in order not to interconnect with life around her. The husband's family is certain that by getting Halima locked up in her room, she is not to touch the outside world. The following passage describes Halima's cultural bondage.

Helping her to settle into the customs in their house, Halima's husband had mentioned the windows. "We always have the slats pointing downwards; otherwise there's no privacy in this room." He had paused, then added, "Ma is very particular about this." 
As the days passed Halima did notice that whenever her mother-in-law came to her room, her eyes invariably went to the slats even as she talked to Halima. (Khan, 2010, p. 121)

Here, Halima is given the responsibility, but the right is not given to her - the right to mingle, the right to gain entertainment, the right to be free to live a normal daily life for girls of her age.

Victimization continues in the story. Sexual maturity is quickly obtained by Halima because almost every night she is made an object of sexual satisfaction by her husband. Being treated as an object of lust, not only does she live an unhappy marriage life, she is also prone to physical damage. Child marriage is but sexual exploitation the way prostitution is (Mikhail, 2002). It should also be borne in mind that WHO, UNICEF, and NGOs around the world have established grounds for criminalization on destruction of the reproductive organs suffered by the child bride. The decline in the number of early marriages in Bangladesh, according to Kamal, has increased the country's maternal and child health index (2012, p. 317). Women and children become victims of violence in marriage at a young age, both physical and psychosocial violence.

If seen through gender studies, "Seduction" offers a narrative of violations of women's rights, but there is no solution in them. Halima is depicted as a femme fatale or seductive female (Dewi, 2016: 130). The appearance of female trappers with aura of enchantment and mystery always color the literary works since the ancient and classical (see Braun, 2012), until the contemporary times primarily in novels and western films at the end of the $20^{\text {th }}$ century. Such characters as Delilah, Salome, Cleopatra, Helen of Troy get transformed into beautiful girls in the James Bond film. This kind of objectification is inseparable from Orientalist view which became the core of postcolonial studies (Dewi, 2018).

Though there is no infidelity between Halima and the chai man, "adultery" through the eyes is plainly illustrated as she peeks through the window admiring how well-built the young man is:

[The biceps] bulged through the half sleeve of his safari shirt as he stood poised over the cup of tea with the heavy kettle in the midair. She wondered how it would feel to the touch. She closed her eyes and a stillness came over her, and when she opened her eyes the stillness was mirrored in the eyes of the Chaiwallah. His left brow shot up and he gave his quirky smile. Halima's heart thundered away but she did not lower her eyes. (Khan, 2010: 128)

The passage above betrays typical sex-innocence of a young woman. Instead, it depicts Halima's sexual/sensual repressions. It is clear here that the narrator put the female character in her position as a victim. Until the story ends, the more obvious is the weakness of Halima. Despite her seemingly rebellious manner as shown in her taking a peek and even sneakily buying tea for herself, the young woman is on the losing side. When Chaiwallah no longer passes in front of her wind for he is now working in a coffee shop, Halima continues to send Ahsan to buy a cup of chai even if she has to pay four times more expensive. Here, instead of breaking the rope of violence against her, Halima in reality accepts the conditions and consequences of early marriage, that is, the marriage that has made the child bride physically and spiritually burdened. 
Similarly, "Inem" is evidence that young girls are wed to ease the family's economic problem. The story is one of Pram's early works along with 10 other short stories compiled in Stories from Blora. "The twenty-nine months in the Dutch captivity to Pram is a time of experience, mentality, thought and imagination that matures and enriches the soul," H. B. Jasin writes in his introduction to the reprinted edition of the short stories collection (in Toer, 1994, p. vi). Indeed, Pram's childhood experiences, criticism of the feudal culture, and his anxiety over the justice in society are characteristic of the works of the Maestro (Hatley, 1980; Dewi, 2013).

Child marriage is considered commonplace among families living in the poor area that becomes the setting of Pram's story. It would seem that Inem, like probably most girls in her kampong, is thrilled when telling her little young master about her marriage: "The proposal came a week ago. My folks and all my other relatives think it's a good idea." Though astonished that Inem is only two years older than him, Muk comments cheerfully, "Wow! That'll be fun!" (Toer, 2004 , p. 31) That marriage means alleviation of poverty is apparent in Inem's enthusiastic rejoinder described below:

"It sure will," she agreed. "They'll buy me all these beautiful new clothes.

And I'll get to wear a bride's dress and have flowers in my hair and powder, mascara, and eye shadow. I'm going to like that!' (Toer, 2004, pp. 31-32)

Conversely, Muk's mother, who is of higher social status, gives a different reaction thus: "And just a child! Eight years old. Such a shame. But they need money, I suppose, and the only way to get it is by marrying off their daughter." (Toer, 2004, p. 37) The mother character who is reportedly inspired by Pram's own mother tries hard to explain to Inem's mother not to let Inem get married in such a young age by repeatedly saying "It's not right for children to marry" for fear that "their children will be stunted [and] their health will be poorly affected" (Toer, 2004, pp. 35-36). As a note in passing, the Acting Director of Reproductive Health, National Population and Family Planning Agency (BKKBN) Widwiono recently claims that a mother younger than 18 years old is incapable of taking care of her baby optimally (cited in KOMPAS, August 2, 2018, p. 10). The same report says that based on the 2012 Indonesian Demographic and Health Survey, the maternal mortality rate reached 359 deaths per 100,000 births.

But the effort of Muk's mother to explain about the risk of early marriage is fruitless because Inem's mother unwaveringly believes that nothing is wrong about early marriage. Having previously detailed Inem's future husband, i.e., Markaban son of a rich man and an only child, Mbok Inem is puzzled why Muk's mother should be overly worried about Inem's getting marriage. Pram describes the different views between the two women as follows.

'I'm sure you're right, ma'am, but my own family is long-lived. My mother is still alive and she's at least fifty-nine. My grandmother is living, too. She must be about seventy-four. And she's still strong, strong enough to pound corn, anyway."

Still ignoring her, Mother added, "Especially if the husband is young, too."

"Of course, ma'am, but Markaban is seventeen." 
"Seventeen! My husband was thirty when he married me." (Toer, 2004, p. 36)

The conversation between the two women of different social status concerning early marriage clearly shows the gulf that socially separates them. Pram's criticism to feudalism is shown by the term "Ndoro" (in the original version of the story) meaning "Ma'am" used by Inem's mother to address the narrator's mother (see Toer, 1994, p. 41). Thus, by showing two contrasting concepts of marriage and its consequences, Pram underscores the economic and educational disparities that fertilize early marriage practices. This short story also offers a counter-ideology against child marriage, which in this case is represented by the upper-middle class family like the mother of Muk. The characterization of narrator's mother breaks the assumption that all third-world women passively accept the oppression and subordination of patriarchal ideology.

Pram's criticism of child marriage is put in the mouth of 6-year-old Muk who cannot stand hearing Inem's screaming in pain when beaten and forced to serve the biological needs of her husband. As such, this short story effectively calls for justice for the weak and the marginalized. Whenever Muk ask his mother why Inem is crying out "in time with a thudlike sound and then pounding on a door", Mother gives this simple answer: "They're fighting." (Toer, 2004, p. 42) If Muk urges again why Inem and her husband should fight, Muk's mother never gives him a satisfactory answer but saying this only: "Such a pity, such a poor little thing..." (Toer, 2004, p. 43) Thus, through postcolonial reading, Pram's cynical comment is all the more palpable in the closing paragraph: "I'd often hear her cries of pain and when she screamed, I cover my ears with my hands. Meanwhile, Mother continued to uphold propriety and the family's good name." (Toer, 2004, p. 47)

Like Inem as well as the Bangladeshi child bride Halima, Minem and her sibling in Tohari's short story also wed in their young age - all marry into money. In both stories with Indonesian (Java) settings, however, early marriage for girls is not only economical but it also makes the parents proud. Through the characterization of Minem's father, it is inferred that having his two daughters "fly fast off the shelves" makes him delighted (Tohari, 2015, p. 33). One can compare Minem's father here with the anxiety shown by Inem's mother in Pram's story discussed earlier should her daughter accept no marriage proposal, saying: "I just feel lucky someone's proposed [...] and if we let this proposal go by, there might not be another one. Imagine the shame of having a daughter become an old maid! Besides, once she's married she might even be able to help lighten the load around the house." (Toer, 2004, p. 34) It is clear here that for the Javanese society in the 1950s (and perhaps even today), early marriage for daughters makes the family brim with pride.

When compared to Halima and Inem, it would seem that Minem belongs to women survivors, not victims. The male characters, ironically, come across as timid, if not to say cowardice. Not only is Kasdu cast as lazy, but he is also weak. Tohari describes how this husband of Minem is impressed with "how Minem bore the extreme pain... held her breath and contracted her belly so that the baby would be pushed out." (Tohari, 2015, p. 29) Although Kasdu is concerned about the safety of Minem and her baby, negligence of his pregnant wife is a form of violence. 
It is also interesting to look further at the actions of Kasdu's father-in-law. Unlike Kasdu, Minem's father seems less concerned about the pain of his own child. After being rebuked by his wife not to over-respond to the birth of her premature grandchild, the man said: "Yes, yes. But I'm still amazed. It turns out that not only a mature woman can give birth to a baby, a little girl can do it also." (Tohari, 2015, p. 33) Now it is clear that in this short story, normalization of violence is delivered in a joking tone. Minem's father's jokes about babies that are likened to eggs or meat are but verbal violence. The feminist perspectives help to uncover Tohari's criticism of marriage at a young age that harms women vis-à-vis male egoism.

Nevertheless, reading this short story with emphatic understanding accompanied by a sense of taste, one can see that the tradition of early marriage is but common existence in poor areas. Tohari extensively described Minem's arid village where "little boys with cracked skin" scavenged dry twigs and broken branches for firewood and gadung yam, cassava remnants in stony soil (Tohari, 2015, p. 28). Tohari's depiction of hollow in the ground that used to be a stream without a single drop of water, dried molten trees, rock-hard soils, and so forth helps reinforce the picture of people who live in poverty. For this impoverished population, child marriage is a solution. The paradoxical effect is juxtaposed herein: the dryness of nature and the fertility of the child bride's womb.

\section{Conclusion}

This article has shown that there are similarities and differences in "Seduction", "Inem", and "Minem Gave Birth to a Baby" in representing child marriage. They all open with events experienced by the female characters who are married at their young age. Life does not immediately become good after these women put an abrupt end to their childhood - a time of playing and schooling. The extent to which the female characters can be seen as victims, survivors, or victors of early marriage differs from one case to another and to the third. The story from Bangladesh by Khan depicts Halima the child bride as a victim of patriarchy, while the Indonesian child brides in the stories relatively survive the hardship of following early marriage tradition. Pram's Inem however is not as successful as Tohari's Minem. Although both young women endure the difficulty, the former is left out, while the latter is welcomed by the family.

This study has also shown that the varied imaginations of child marriage in the stories studied are inseparable from the cultural context upon which each story is drawn. Apparently, "Seduction" is presented to readers in the Western world who tend to assume that the exploitation of women is but exoticism of the local culture, particularly through the depiction of sexual repression experienced by the main character, i.e. a copied figure of temptress in Western literature. Conversely, child marriage in "Minem Gave Birth to a Baby" is displayed with a little jest as a natural, everyday thing and there is no element of coercion in the matter, since early marriage has been a long-standing practice in the village that becomes the setting of the story. The normalization of violence in Tohari's short story is thus proven through the presence of a tough and self-controlled female character, while in Khan's, the young woman character comes across as troubled and repressed. But criticism against child marriage is most obvious in "Inem" in that normalization of violence perpetrated by men against women is scarcely shown 
herein. There is an attempt, even if it fails, to break the violence of child marriage in this early story of Pram

Therefore, this paper concludes that victimization toward child brides in the three stories occurs in varying degrees. The female protagonists are all too young to wed; and, worse still, they are too weak to defend themselves against patriarchal system. Gender issues in the story from Bangladesh, however, are not the same when placed within the context of the Indonesian stories. In the hope of ending the practice of early marriage, these short stories have all invited further reading to reveal the complexity of gender and multicultural cultures as diverse as Bangladesh and Indonesia. When more transformative writing and reading of child bride stories is available, the world would require no more heart-rending stories to put an end to early marriage like those reported in the National Geographic magazine quoted in the beginning of this article.

\section{References}

Ang, I. (2003). I'm a feminist but... 'Other' women and postnational feminism. In R. Lewis \& S. Mills (Editor) Feminist Postcolonial Theory: A Reader (190206). London: Routledge.

Anonymous. (2018). Nikah dini tingkatkan risiko kematian ibu. KOMPAS, August 2, p. 10.

Anonymous. (2015). Plan International, Getting the Evidence: Asia Child Marriage Initiative. Retrieved on December 13, 2016 from https://planinternational.org/worldwide-annual-review-2015

Braun, H. L. (2012). The rise and fall of the femme fatale in British literature, 1790-1910. Madison: Fairleigh Dickinson University Press.

Dewi, N. (2013). Women of will for nation building in Pramoedya's three early novels. Kritika Kultura Journal of Literary/cultural and Language Studies, (20), $1-20$. http://journals.ateneo.edu/ojs/index.php/kk/article/view/KK2013.02001/838

Dewi, N. (2016). Melawan normalisasi kekerasan: Perkawinan bocah dalam dua cerpen Asia. In H. Setiajid (Editor) Prosiding Seminar Nasional Sastra dan Politik Partisan (127-134). Yogyakarta: Universitas Sanata Dharma.

Dewi, N. (2017). Under children's eyes: Becoming pious in Tayeb Salih and Pramoedya Ananta Toer short stories. Al-Jami'ah: Journal of Islamic Studies, $55(1)$ 27-46. http://aljamiah.or.id/index.php/AJIS/article/view/700/294ol.

Dewi, N. (2018) Postcolonial hermeneutics: Concepts and contribution to understanding socio-religious problems in Southeast Asia. IKAT: The Indonesian Journal of Southeast Asian Studies, 2(1), 47-66. https://doi.org/10.22146/ikat.v2i1.37392.

Harlan, Becky. (2015). Documenting child marriage for over a decade and still going. $\quad$ National

Geographic http://proof.nationalgeographic.com/2015/09/14/documenting-childmarriage-for-over-a-decade-and-still-going/

Hatley, B. (1980). Blora revisited. Indonesia, (30), 1-16.

Kamal, S.M.M. (2012). Decline in child marriage and changes in its effect on reproductive outcomes in Bangladesh. Journal of Health, Population and 
Nutrition, 30(3), 317-33. Retrieved on May 25, 2018, from http://www.jstor.org/stable/23500187

Khan, R. S. (2010). Seduction. In M.A. Quayum (Editor). A Rainbow Feast: New Asian Short Stiries (119-131). Singapore: Marshall Cavendish.

Mikhail, S. L. B. (2002). Child marriage and child prostitution: Two forms of sexual exploitation. Gender and Development, 10(1), 43-49. Retrieved on November 23, 2016, from http://www.jstor.org/stable/4030681

Mohanty, C. T. (2003). "Under western eyes" revisited: Feminist solidarity through anticapitalist struggles. Signs: Journal of Women in culture and Society, 28(2), 499-535.

Okin, S. M. (1998). Feminism and multiculturalism: Some tensions. Ethics, 108(4), 661-684.

Subramanian, N. (2010). Making family and nation: Hindu marriage law in early postcolonial India. The Journal of Asian Studies, 69(3), 771-798. https://doi.org/10.1017/S0021911810001476.

Suleri, S. (1992). Woman skin deep: Feminism and the postcolonial condition. Critical Inquiry, 18(4), 756-69. http://www.jstor.org/stable/1343829?seq=1\#page_scan_tab_contents

Susetyo, H. (2008, November 28). Pernikahan di bawah umur: Tantangan legislasi dan harmonisasi hukum, Hukum Online. Retrieved on July 15, 2018, from http://www.hukumonline.com/berita/baca/hol20594/pernikahan-di-bawahumur-tantangan-legislasi-dan-harmonisasi-hukum

Toer, P. A. (1994). Cerita dari Blora: Kumpulan Cerita Pendek. Jakarta: Hasta Mitra.

Toer, P. A. (2004). Inem. In W. Samuels. All That Is Gone (31-48), trans. New York: Hyperion.

Tohari, A. (2015). Minem Gave Birth to a Baby. In R. Kesauly. Karyamin's Smile (27-33), trans. Jakarta: PT Gramedia Pustaka Utama.

Volpp, L. (2001, June). Feminism versus multiculturalism. Columbia Law Review, 101(5), 1181-1218.Retrieved on February 19, 2010, from http://www.jstor.org/stable/1123774. 